\title{
Article
}

\section{Titanium Dioxide Nanoparticles Exacerbate Allergic Airway Inflammation via TXNIP Upregulation in a Mouse Model of Asthma}

\author{
Je-Oh Lim ${ }^{1}{ }^{1}$, Se-Jin Lee ${ }^{1}$, Woong-Il Kim ${ }^{1}$, So-Won Pak ${ }^{1}$, Changjong Moon ${ }^{1}{ }^{\circledR}$, In-Sik Shin ${ }^{1}{ }^{\circledR}$, Jeong-Doo Heo ${ }^{2}$, \\ Je-Won Ko ${ }^{3, *}$ and Jong-Choon Kim ${ }^{1, *}$
}

check for

updates

Citation: Lim, J.-O.; Lee, S.-J.; Kim, W.-I.; Pak, S.-W.; Moon, C.; Shin, I.-S.; Heo, J.-D.; Ko, J.-W.; Kim, J.-C. Titanium Dioxide Nanoparticles Exacerbate Allergic Airway Inflammation via TXNIP Upregulation in a Mouse Model of Asthma. Int. J. Mol. Sci. 2021, 22, 9924 https://doi.org/10.3390/ijms22189924

Academic Editors: Kalevi Kairemo and Daniela Montesarchio

Received: 9 August 2021

Accepted: 10 September 2021

Published: 14 September 2021

Publisher's Note: MDPI stays neutral with regard to jurisdictional claims in published maps and institutional affiliations.

Copyright: (c) 2021 by the authors. Licensee MDPI, Basel, Switzerland. This article is an open access article distributed under the terms and conditions of the Creative Commons Attribution (CC BY) license (https:/ / creativecommons.org/licenses/by/ $4.0 /)$.
1 College of Veterinary Medicine (BK21 FOUR Program), Chonnam National University, Gwangju 61186, Korea; dvmljo@gmail.com (J.-O.L.); xhdhksd1123@naver.com (S.-J.L.); dvmwoong@gmail.com (W.-I.K.); sowonp0112@gmail.com (S.-W.P.); moonc@chonnam.ac.kr (C.M.); dvmmk79@gmail.com (I.-S.S.)

2 Bioenvironmental Science \& Technology Division, Korea Institute of Toxicology, Jinju 52834, Korea; jdher@kitox.re.kr

3 College of Veterinary Medicine, Chungnam National University, Daejeon 34131, Korea

* Correspondence: rheoda@cnu.ac.kr (J.-W.K.); toxkim@jnu.ac.kr (J.-C.K.); Tel.: +82-42-821-6752 (J.-W.K.); +82-62-530-2827 (J.-C.K.)

Abstract: Titanium dioxide nanoparticles $\left(\mathrm{TiO}_{2} \mathrm{NPs}\right)$ are widely used in industrial and medicinal fields and in various consumer products, and their increasing use has led to an increase in the number of toxicity studies; however, studies investigating the underlying toxicity mechanism have been rare. In this study, we evaluated potential toxic effects of $\mathrm{TiO}_{2} \mathrm{NPs}$ exposure on lungs as well as the development of asthma through the ovalbumin (OVA)-induced mouse model of asthma. Furthermore, we also investigated the associated toxic mechanism. $\mathrm{TiO}_{2} \mathrm{NPs}_{\text {caused pulmonary }}$ toxicity by exacerbating the inflammatory response, indicated by an increase in the number and level of inflammatory cells and mediators, respectively. OVA-induced asthma exposed mice to $\mathrm{TiO}_{2} \mathrm{NPs}$ led to significant increases in inflammatory mediators, cytokines, and airway hyperresponsiveness compared with those in non-exposed asthmatic mice. This was also accompanied by increased inflammatory cell infiltration and mucus production in the lung tissues. Additionally, $\mathrm{TiO}_{2} \mathrm{NPs}$ decreased the expression of B-cell lymphoma 2 ( $\mathrm{Bcl} 2)$ and the expressions of thioredoxin-interacting protein (TXNIP), phospho-apoptosis signal-regulating kinase 1, Bcl2-associated $X$, and cleavedcaspase 3 were escalated in the lungs of asthmatic mice compared with those in non-exposed asthmatic mice. These responses were consistent with in vitro results obtained using human airway epithelial cells. $\mathrm{TiO}_{2} \mathrm{NPs}$ treated cells exhibited an increase in the mRNA and protein expression of interleukin (IL)-1 $\beta$, IL-6, and tumor necrosis factor- $\alpha$ with an elevation of TXNIP signaling compared to non-treated cells. Moreover, pathophysiological changes induced by $\mathrm{TiO}_{2} \mathrm{NP}$ treatment were significantly decreased by TXNIP knockdown in airway epithelial cells. Overall, $\mathrm{TiO}_{2} \mathrm{NP}$ exposure induced toxicological changes in the respiratory tract and exacerbated the development of asthma via activation of the TXNIP-apoptosis pathway. These results provide insights into the underlying mechanism of $\mathrm{TiO}_{2} \mathrm{NP}$-mediated respiratory toxicity.

Keywords: titanium dioxide nanoparticle; asthma; airway inflammation; thioredoxin-interacting protein; apoptosis

\section{Introduction}

Air pollutants such as yellow and fine dust, have become a critical social issue and are life-threatening to patients with respiratory diseases. Several studies [1-4] have particularly reported that titanium dioxide nanoparticles $\left(\mathrm{TiO}_{2} \mathrm{NPs}\right)$, components of Asian dust and air pollutants, exacerbate respiratory distress [1-4]. Moreover, $\mathrm{TiO}_{2} \mathrm{NPs}$ induce an intensive inflammatory response by triggering inflammatory cell migration and pro-inflammatory 
cytokine secretion, consequently contributing to the development and exacerbation of respiratory diseases [5,6]. However, mechanisms associated with the toxic effects of titanium on the respiratory system and its diseases have not been clearly identified.

Of the known respiratory diseases, asthma is an inflammatory disease of the respiratory airways that affects approximately 300 million people globally [7]. It is characterized by excessive inflammation of bronchi and obstruction of the airflow due to increased immune responses, resulting in varying respiratory symptoms, mainly difficulty in breathing, wheezing, coughing, and tightness in the chest $[3,8,9]$. Based on its main characteristics, asthma has been divided into molecular pathways/clinical presentations or atopic/nonatopic asthma and more recently, into eosinophilic or non-eosinophilic phenotypes based on biological mechanisms [10]. Proinflammatory cytokines are key players in the development and progression of asthma, and they induce elevated immune responses, resulting in characteristic asthmatic responses such as eosinophilia, airway hyperresponsiveness (AHR), airway remodeling, and mucus production [11]. Previous studies have shown that fine dust and air pollutants aggravate asthma; however, the underlying toxicity mechanism is not well established.

Thioredoxin-interacting protein (TXNIP), a critical regulator of pathological responses, is induced by various of stressors including inflammation, metabolic dysfunction, apoptosis, and lung dysfunction [12-14]. TXNIP has been expressed in the lungs of experimental animals exposed to lipopolysaccharide and ovalbumin (OVA), which induce increased inflammatory responses via the activation of inflammasomes [15-17]. In contrast, TXNIP is involved in the apoptotic response of lung tissues. Elevation of TXNIP expression by various stimuli results in the activation of apoptotic signaling molecules such as mitochondrial apoptosis signal-regulating kinase 1 (ASK1), B-cell lymphoma 2 associated X (Bax), p38 mitogen-activated protein kinase, and cleaved-caspase 3 (Cas3), which eventually trigger the apoptosis of lung tissues $[18,19]$. The association between $\mathrm{TiO}_{2} \mathrm{NPs}$ and apoptosis under asthmatic conditions has not been clearly established. Therefore, an in-depth study is needed to understand the apoptosis mechanisms triggered via TXNIP in OVA-induced mice and how $\mathrm{TiO}_{2} \mathrm{NPs}$ pathologically exacerbate the development of asthma.

In this study, we investigated the exacerbation of asthma in response to $\mathrm{TiO}_{2} \mathrm{NP}$ exposure in OVA-induced asthmatic mice and explored the underlying mechanisms involving TXNIP and apoptosis.

\section{Results}

\subsection{Physicochemical Characterization of $\mathrm{TiO}_{2} \mathrm{NPS}$}

The morphology, primary, and hydrodynamic sizes of $\mathrm{TiO}_{2} \mathrm{NPs}$ are shown in Figure 1. The primary and hydrodynamic sizes in phosphate-buffered saline (PBS) were $48.89 \pm 15.49$ and $238.94 \pm 57.94 \mathrm{~nm}$, respectively. The specific surface area of $\mathrm{TiO}_{2} \mathrm{NPs}$ was 40.45 and $39.38 \mathrm{~m}^{2} / \mathrm{g}$ as determined using the Brunauer-Emmett-Teller (BET) and single point methods, respectively (Table 1). The zeta potential of the $\mathrm{TiO}_{2} \mathrm{NPs}$ was $-31.01 \mathrm{mV}$ (Figure 1c). Purity of $\mathrm{TiO}_{2} \mathrm{NPs}$ was measured as $21.35 \%$ of $\mathrm{Ti}$ and $78.65 \%$ of $\mathrm{O}$ using energy-dispersive X-ray spectroscopy (Figure $1 \mathrm{~d}$ ). $\mathrm{TiO}_{2} \mathrm{NP}$ suspensions did not show detectable endotoxin levels (data not shown). $\mathrm{TiO}_{2} \mathrm{NP}$ concentrations in the lung tissues were determined using inductively coupled plasma mass spectrometry (ICP-MS) (Table 1); the amount of $\mathrm{TiO}_{2} \mathrm{NPs}$ in the $\mathrm{TiO}_{2} \mathrm{NPs}$-treated groups was markedly increased in a dose-dependent manner compared with that in the vehicle control (VC) group. 
(a)
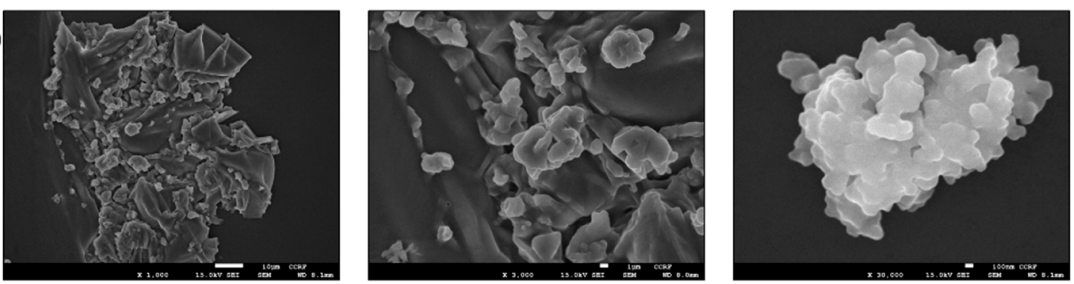

(b)
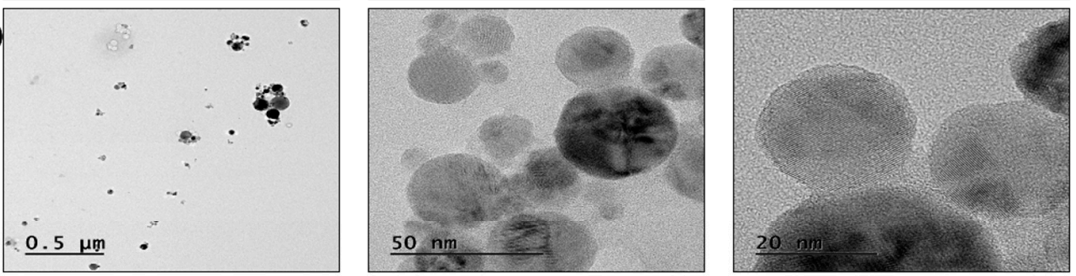

(c)
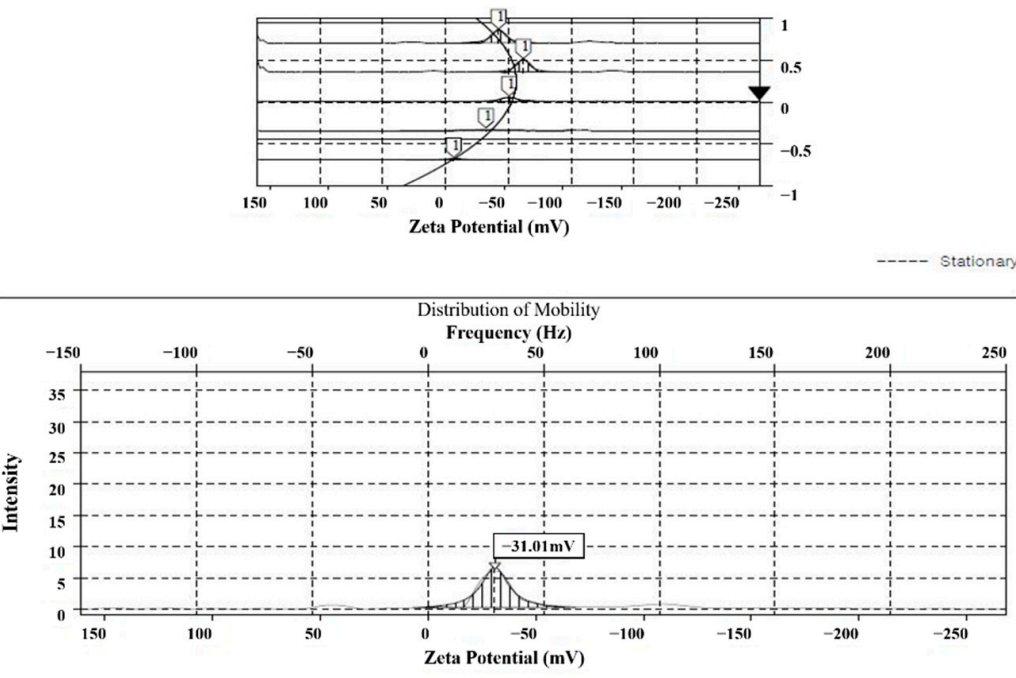

(d)

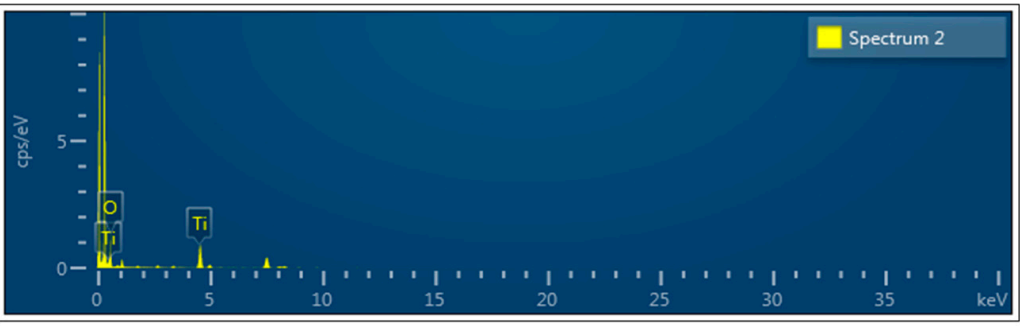

(e)

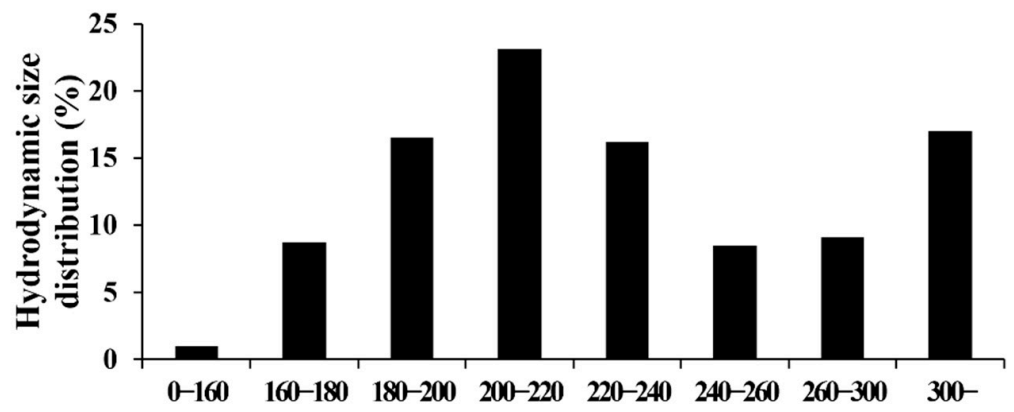

Figure 1. Morphology and physicochemical properties of $\mathrm{TiO}_{2} \mathrm{NPs}$. (a) Morphology of $\mathrm{TiO}_{2} \mathrm{NPs}_{\text {sas }}$ measured using transmission electron microscopy. Scale bars represent 10, 1, and $0.1 \mu \mathrm{m}$, respectively. (b) Morphology of $\mathrm{TiO}_{2} \mathrm{NPs}$ was measured using scanning electron microscopy. (c) Zeta potential of $\mathrm{TiO}_{2} \mathrm{NPs}$ was measured using ELS-8000 (-31 mV). (d) Purity of $\mathrm{TiO}_{2} \mathrm{NPs}$ was measured using energy-dispersive X-ray spectroscopy (Ti: $21.35 \%$, O: $78.65 \%$ ). (e) Hydrodynamic size of $\mathrm{TiO}_{2} \mathrm{NPs}$ in PBS solution was measured using ELS-8000. 
Table 1. Surface area and ICP-MS measurements of $\mathrm{TiO}_{2} \mathrm{NPs}$.

\begin{tabular}{|c|c|c|c|c|c|}
\hline BET Surface Area $\left(\mathrm{m}^{2} / \mathrm{g}\right)$ & \multicolumn{5}{|c|}{ ICP-MS (mg/g) } \\
\hline \multirow{2}{*}{40.45} & $\mathrm{VC}$ & & $\mathrm{TiO}_{2} \mathrm{NPs} 5$ & $\mathrm{TiO}_{2} \mathrm{NPs} 10$ & $\mathrm{TiO}_{2} \mathrm{NPs} 20$ \\
\hline & $0.38 \pm 0.032$ & & $2.88 \pm 0.311$ & $5.68 \pm 0.597$ & $6.69 \pm 0.613$ \\
\hline $\begin{array}{l}\text { Single point Surface area } \\
\qquad\left(\mathrm{m}^{2} / \mathrm{g}\right)\end{array}$ & $\mathrm{VC}$ & OVA & $\begin{array}{c}\mathrm{OVA}+ \\
\mathrm{TiO}_{2} \mathrm{NPs} 5\end{array}$ & $\begin{array}{c}\text { OVA + } \\
\mathrm{TiO}_{2} \mathrm{NPs} 10\end{array}$ & $\begin{array}{c}\text { OVA + } \\
\mathrm{TiO}_{2} \mathrm{NPs} 20\end{array}$ \\
\hline 39.38 & $0.34 \pm 0.056$ & $0.32 \pm 0.042$ & $2.53 \pm 0.397$ & $6.43 \pm 0.617$ & $7.94 \pm 0.673$ \\
\hline
\end{tabular}

Abbreviations: BET, Brunauer-Emmett-Teller; ICP-MS, inductively coupled plasma mass spectrometry; VC, vehicle control group; OVA, ovalbumin challenge + phosphate-buffered saline intranasal instillation group; $\mathrm{TiO}_{2} \mathrm{NP} 5,10$, and 20 intranasal instillation groups with 5 , 10 , and $20 \mathrm{mg} / \mathrm{kg}$ of $\mathrm{TiO}_{2} \mathrm{NPs}$, respectively; and OVA $+\mathrm{TiO}_{2} \mathrm{NPs} 5,10$, and 20 intranasal instillation groups of ovalbumin challenge $+5,10$, and $20 \mathrm{mg} / \mathrm{kg}$ of $\mathrm{TiO}_{2} \mathrm{NPs}$, respectively.

\subsection{Effects of $\mathrm{TiO}_{2} \mathrm{NPs}$ on $\mathrm{AHR}$ and Inflammatory Cell Counts}

In the pulmonary toxicity study, exposure to $\mathrm{TiO}_{2} \mathrm{NPs}$ significantly increased inflammatory cell counts in the bronchoalveolar lavage fluid (BALF) of mice compared with the BALF of VC mice. In particular, a marked increase in the number of neutrophils and macrophages was observed (Figure S1). BALF of the OVA group exhibited a significant increase in inflammatory cell counts, especially that of eosinophils, compared to that of BALF of the VC group (Figure 2a). OVA-induced mice exposed to $\mathrm{TiO}_{2} \mathrm{NPs}$ exhibited elevated counts of eosinophils, macrophages, and neutrophils compared with the OVA group, and this increase occurred in a dose-dependent manner. As shown in Figure 2b, the mean Penh value was augmented in the OVA group compared with the VC group. Furthermore, Penh values exhibited dose-dependent increases in the OVA $+\mathrm{TiO}_{2} \mathrm{NP}$ mice compared with the OVA mice (Figure $2 b$ ).

\subsection{Effects of $\mathrm{TiO}_{2} \mathrm{NPs}$ on Cytokine Production and OVA-Specific IgE Levels in Serum}

To determine whether $\mathrm{TiO}_{2} \mathrm{NPs}$ affect the production of inflammatory cytokines in addition to increasing the number of inflammatory cells, cytokine levels in BALF samples were measured. The pulmonary toxicity study revealed that levels of proinflammatory cytokines, namely tumor necrosis factor (TNF)- $\alpha$, interleukin (IL)-6, and IL- $1 \beta$, were significantly augmented in $\mathrm{TiO}_{2} \mathrm{NP}$-treated groups compared with those in the VC group (Figure S2). Levels of TNF- $\alpha$, IL-6, and IL-1 $\beta$ in BALF were also significantly greater in the OVA group compared with those in the VC group. Exposure to $\mathrm{TiO}_{2} \mathrm{NPs}$ increased levels of TNF- $\alpha$, IL- 6 , and IL- $1 \beta$ compared with those in the OVA group; this increase was dose-dependent (Figure 3a-c). Similar to levels of TNF- $\alpha$, IL-6, and IL-1 $\beta$, levels of IL-5 and IL-13 in BALF were also higher in the OVA group. Moreover, levels of IL-5 and IL-13 were increased dose-dependently (Figure 3d,e) and the OVA-specific IgE level in the serum was elevated in the $\mathrm{TiO}_{2} \mathrm{NP}$-treated groups compared to that in the OVA group (Figure $3 \mathrm{f}$ ).

\subsection{Effects of $\mathrm{TiO}_{2} \mathrm{NPs}$ on Airway Inflammation and Mucous Secretion in OVA-Induced Mice}

Mice exposed to $\mathrm{TiO}_{2} \mathrm{NPs}$ showed an accumulation of inflammatory cells around the alveoli and bronchi as well as increased mucus production (Figure S3). OVA-induced mice showed a significantly higher degree of airway inflammation than VC mice. When the OVA-induced mice were treated with $\mathrm{TiO}_{2} \mathrm{NPs}$, airway inflammation worsened in a dose-dependent manner compared to that in OVA-induced mice (Figure 4a). Changes in the mucus production index exhibited a pattern similar to changes in airway inflammation wherein mucus production in the $\mathrm{TiO}_{2} \mathrm{NP}$-treated groups was markedly escalated in a dosedependent manner compared with that in the OVA group (Figure $4 \mathrm{~b}$ ). Moreover, thickening of the basement membrane and airway smooth muscle, vasodilatation, increased number of blood vessels, and goblet cell metaplasia were observed in OVA-induced mice. These pathological changes were more severe in $\mathrm{TiO}_{2} \mathrm{NP}$-treated groups (Figure $4 \mathrm{a}, \mathrm{b}$ ). 

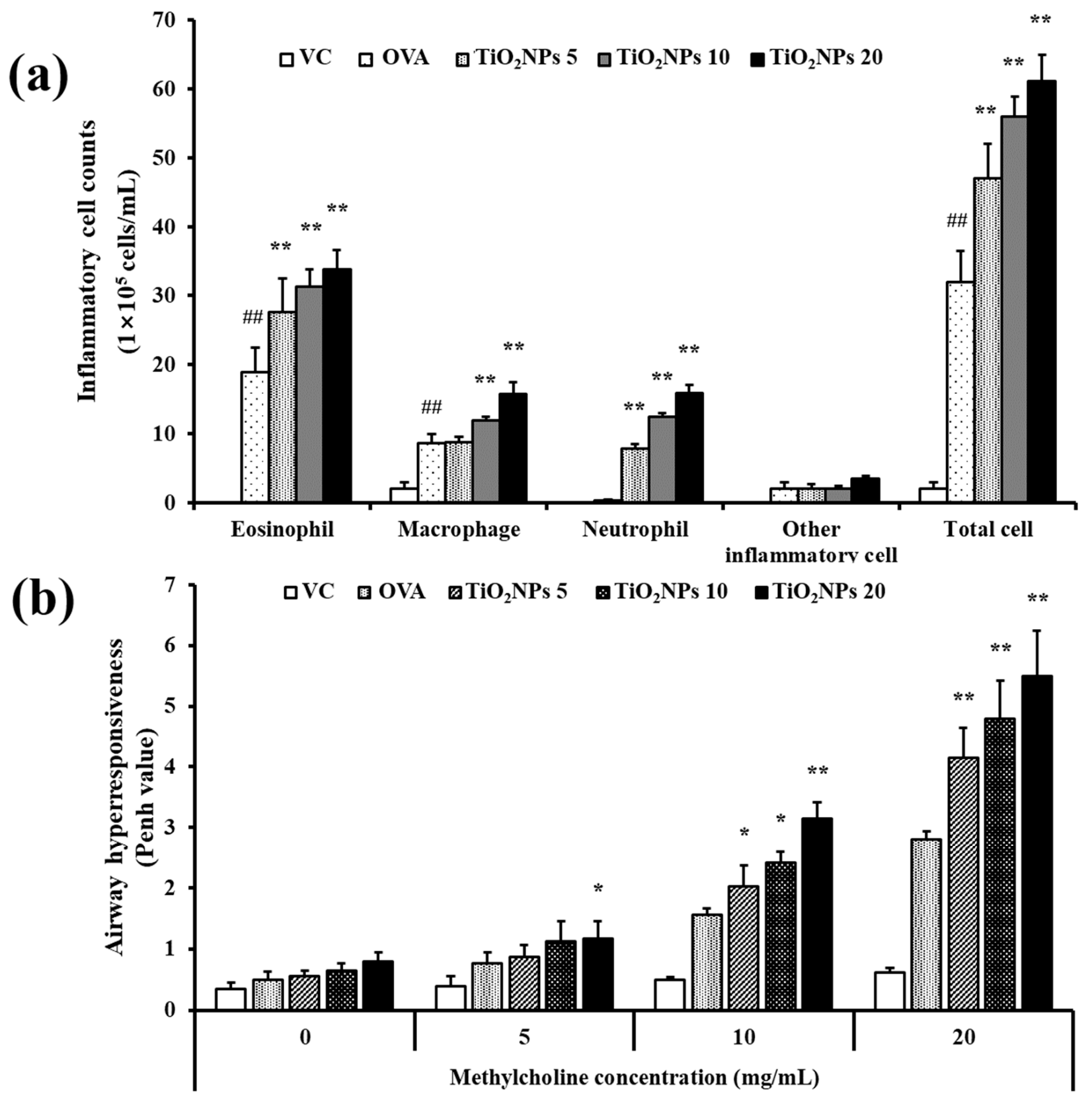

Figure 2. Effects of $\mathrm{TiO}_{2} \mathrm{NP}$ exposure on Penh values and inflammatory cell counts in BALF. (a) Penh values. (b) Inflammatory cell counts. VC, PBS intranasal instillation; OVA, OVA challenge + PBS intranasal instillation; $\mathrm{TiO}_{2} \mathrm{NPs}_{5}, 10$, and 20, OVA challenge $+5,10$, and $20 \mathrm{mg} / \mathrm{kg}$ of $\mathrm{TiO}_{2} \mathrm{NPs}$ intranasal instillation, respectively. Data are represented as means $\pm \mathrm{SD}$, $n=6$. ${ }^{\# \#} p<0.01$, significantly different from the VC group; ${ }^{*} p<0.05,{ }^{* *} p<0.01$, significantly different from the OVA group. 

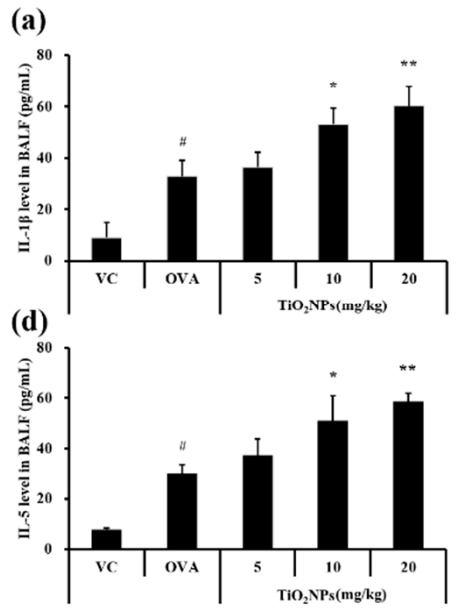

(b)

(e)
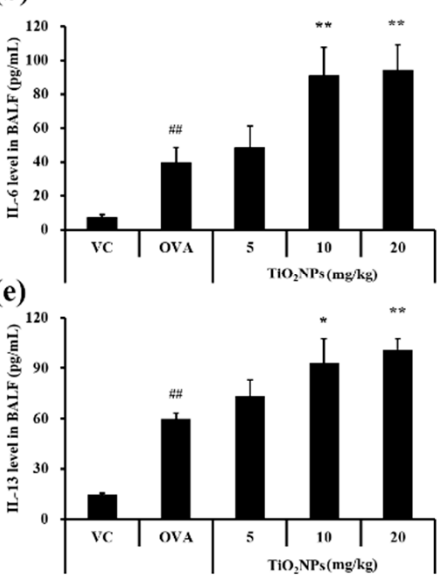

(c)

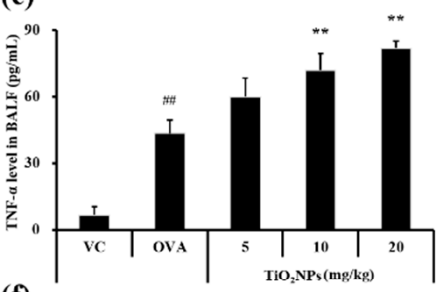

(f)

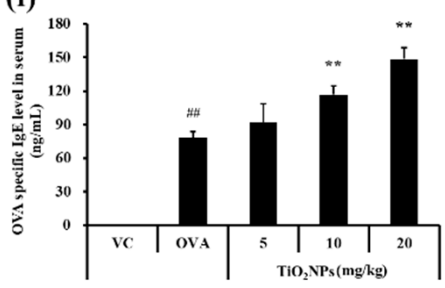

Figure 3. Effects of $\mathrm{TiO}_{2} \mathrm{NP}$ exposure on cytokine levels in BALF and OVA-specific IgE levels in serum. (a) IL-1 $\beta$ level in BALF. (b) IL-6 level in BALF. (c) TNF- $\alpha$ level in BALF. (d) IL-5 level in BALF. (e) IL-13 level in BALF. (f) OVA-specific IgE level in serum. VC, PBS intranasal instillation; OVA, OVA challenge + PBS intranasal instillation; $\mathrm{TiO}_{2} \mathrm{NPs} 5$, 10, and 20, OVA challenge $+5,10$, and $20 \mathrm{mg} / \mathrm{kg}$ of $\mathrm{TiO}_{2} \mathrm{NPs}$ intranasal instillation, respectively. Data are represented as means $\pm \mathrm{SD}$, $n=6$. ${ }^{\#} p<0.05,{ }^{\# \#} p<0.01$, significantly different from the VC group; ${ }^{*} p<0.05,{ }^{* *} p<0.01$, significantly different from the OVA group.

(a)

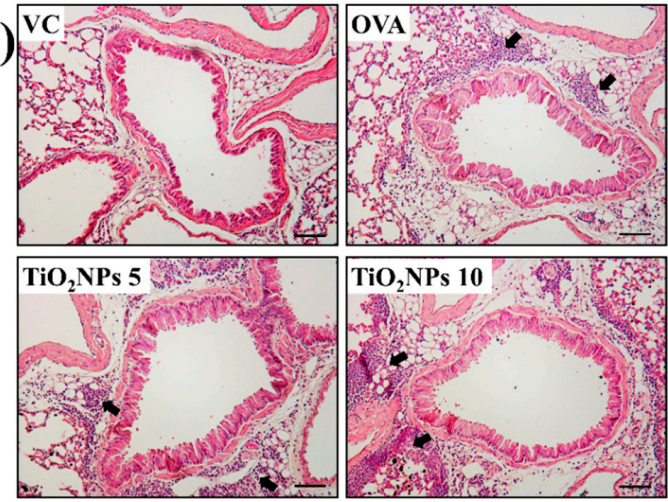

(b)
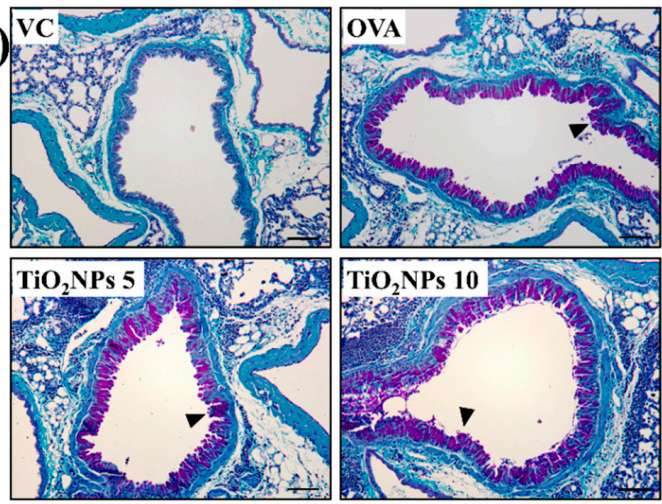
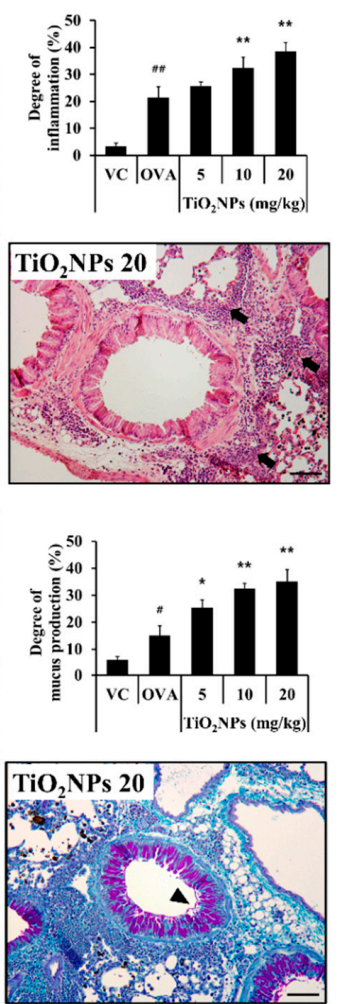

Figure 4. Effects of $\mathrm{TiO}_{2} \mathrm{NP}$ exposure on inflammatory cell infiltration and mucus production in the lungs. (a) Lung tissue is stained with hematoxylin and eosin $(\times 200),(\mathbf{b})$ and periodic acid-Schiff stain $(\times 200)$. VC, $\mathrm{PBS}$ intranasal instillation; OVA, OVA challenge $+\mathrm{PBS}$ intranasal instillation; $\mathrm{TiO}_{2} \mathrm{NPs} 5$, 10 , and 20 , OVA challenge $+5,10$, and $20 \mathrm{mg} / \mathrm{kg}$ of $\mathrm{TiO}_{2} \mathrm{NPs}$ intranasal instillation, respectively. Black arrows indicate inflammatory cell infiltration. Black arrowheads indicate mucus within lung epithelial goblet cells. Data are represented as means $\pm \mathrm{SD}, n=6$. ${ }^{\#} p<0.05,{ }^{\#} p<0.01$, significantly different from the VC group; ${ }^{*} p<0.05,{ }^{* *} p<0.01$, significantly different from the OVA group. Bar $=50 \mu \mathrm{m}$. 


\subsection{Effects of $\mathrm{TiO}_{2} \mathrm{NPs}$ on TXNIP and Apoptotic Protein Expression}

Immunohistochemistry (IHC) was used to estimate expression levels of TXNIP and cleaved-Cas3 in lung tissues in response to OVA and $\mathrm{TiO}_{2} \mathrm{NP}$ treatment. Lungs of normal mice exposed to $\mathrm{TiO}_{2} \mathrm{NPs}$ showed a dose-dependent increase in the expression of TXNIP and cleaved-Cas 3 compared with those of VC mice. Similarly, exposure to $\mathrm{TiO}_{2} \mathrm{NPs}$ led to a surge in the expressions of TXNIP, phospho-ASK1 (p-ASK1), Bax, and cleaved-Cas3 and a decline in the expression of B-cell lymphoma 2 (Bcl2) compared with that in VC mice (Figure S4). TXNIP expression in the OVA group was greater than that in the VC group and increased in a dose-dependent manner in $\mathrm{TiO}_{2} \mathrm{NP}$-treated groups than in the OVA group (Figure 5a). Similarly, cleaved-Cas3 expression in the OVA group increased compared to that in the $\mathrm{VC}$ group and in the $\mathrm{TiO}_{2} \mathrm{NP}$-treated groups compared with that in the OVA group (Figure 5b). The effects of $\mathrm{TiO}_{2} \mathrm{NPs}$ on TXNIP activation were determined using immunoblotting. As shown in Figure 6a,b, TXNIP expression in the lungs was increased in the OVA group compared with the VC group as were the expressions of p-ASK1, Bax, and cleaved-Cas3. However, Bcl2 expression decreased in the OVA group compared with the VC group. Compared with the OVA group, exposure to $\mathrm{TiO}_{2} \mathrm{NPs}$ induced a marked increase in the expression of TXNIP, p-ASK1, Bax, and cleaved-Cas3 in a dose-dependent manner while the $\mathrm{Bcl} 2$ level in $\mathrm{TiO}_{2} \mathrm{NP}$-treated groups was lower than that in the OVA group.

(a)

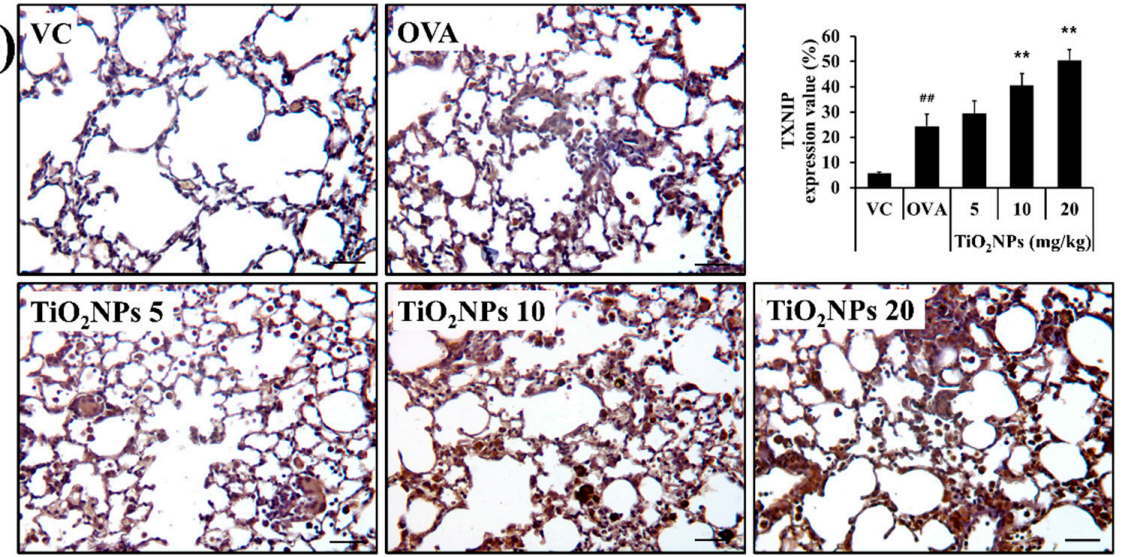

(b)
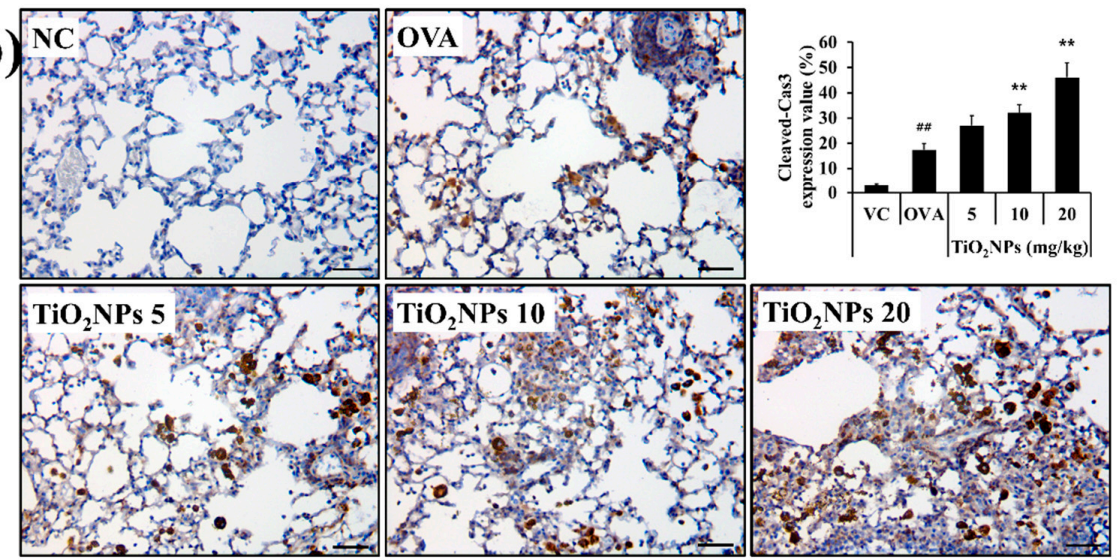

Figure 5. Effects of $\mathrm{TiO}_{2} \mathrm{NP}$ exposure on the expression of TXNIP and cleaved-Cas 3 in the lungs. (a) Expression of TXNIP $(\times 400$, alveolar). (b) Expression of cleaved-Cas3 $(\times 400$, alveolar). VC, PBS intranasal instillation; OVA, OVA challenge + PBS intranasal instillation; $\mathrm{TiO}_{2} \mathrm{NPs} 5,10$, and 20, OVA challenge $+5,10$, and $20 \mathrm{mg} / \mathrm{kg}$ of $\mathrm{TiO}_{2} \mathrm{NPs}$ intranasal instillation, respectively. Data are represented as means $\pm \mathrm{SD}, n=6$. ${ }^{\# \#} p<0.01$, significantly different from the $\mathrm{VC}$ group; $* * 0<0.01$, significantly different from the OVA group. Bar $=50 \mu \mathrm{m}$. 


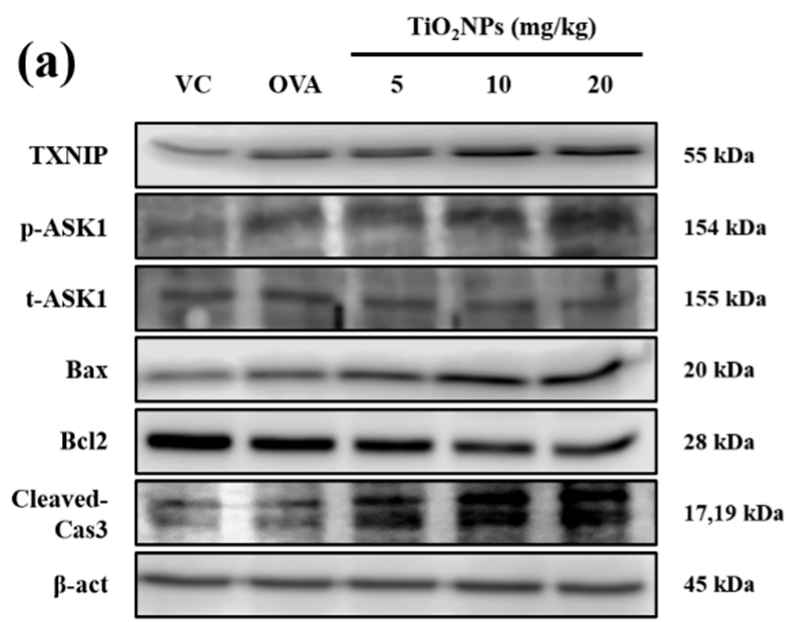

(b)

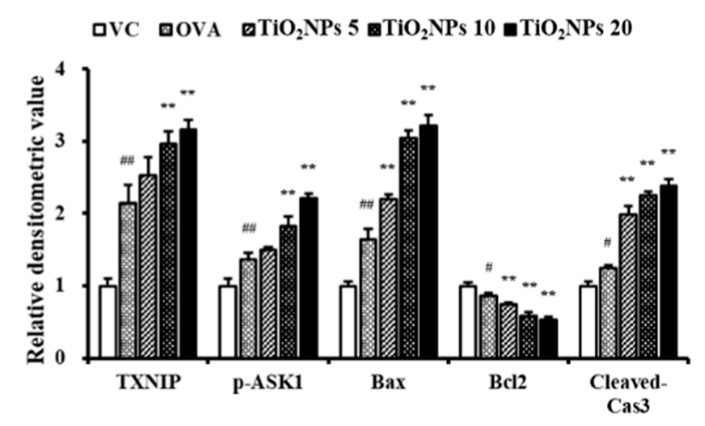

Figure 6. Effects of $\mathrm{TiO}_{2} \mathrm{NP}$ exposure on the expression of TXNIP, p-ASK1, t-ASK1, Bax, Bcl2, and cleaved-Cas3 in the lungs. (a) Protein expression was determined using western blotting. (b) Relative densitometric values of protein expression. VC, PBS intranasal instillation; OVA, OVA challenge + PBS intranasal instillation; $\mathrm{TiO}_{2} \mathrm{NPs} 5,10$, and 20, OVA challenge +5 , 10 , and $20 \mathrm{mg} / \mathrm{kg}$ of $\mathrm{TiO}_{2} \mathrm{NPs}$ intranasal instillation, respectively. Data are represented as means $\pm \mathrm{SD}, n=6$. ${ }^{\#} p<0.05$, ${ }^{\# \#} p<0.01$, significantly different from the VC group; ${ }^{* *} p<0.01$, significantly different from the OVA group.

\subsection{Effects of $\mathrm{TiO}_{2} \mathrm{NPS}$ on the Production of Proinflammatory Mediators in NCI-H292 Cells}

For the in vitro experiments, $\mathrm{TiO}_{2} \mathrm{NP}$ concentrations for treatment groups were decided based on results of the cell viability assay (Figure 7a). Treatment of the $\mathrm{TiO}_{2} \mathrm{NPs}$ significantly elevated the levels of IL-1 $\beta$, IL-6, and TNF- $\alpha$ in NCI-H292 cells in a dosedependent manner compared to the untreated cells (Figure $7 \mathrm{~b}-\mathrm{d}$ ).

(a)

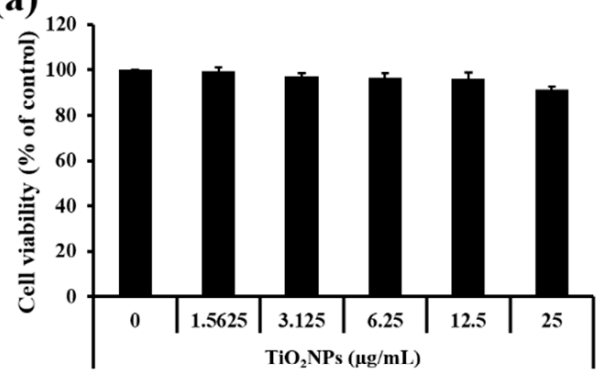

(c)

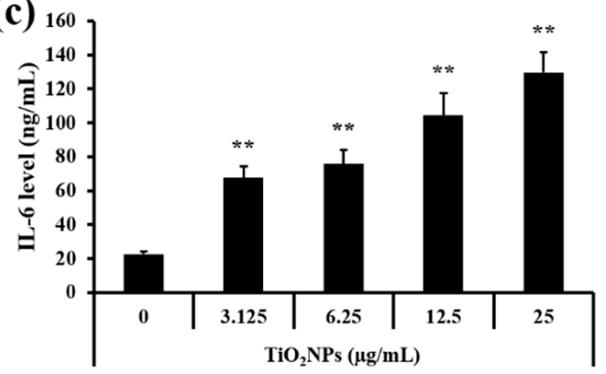

(b)

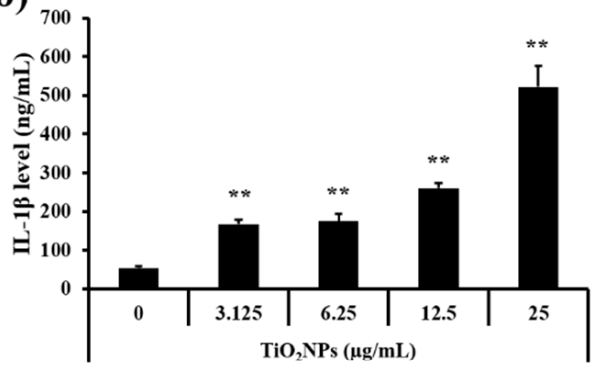

(d)

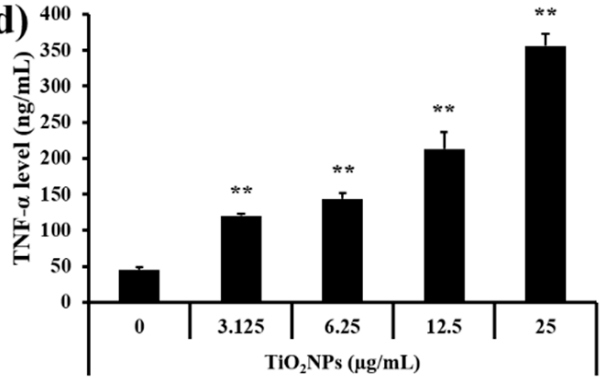

Figure 7. Effects of $\mathrm{TiO}_{2} \mathrm{NP}$ treatment on cell viability and inflammatory cytokines in NCI-H292 cells. (a) Cell viability. (b) IL-1 $\beta$ level. (c) IL-6 level. (d) TNF- $\alpha$ level. Control, PBS treatment; 1.5625, 3.125, $6.25,12.5$, and $25 \mu \mathrm{g} / \mathrm{mL}$ of $\mathrm{TiO}_{2} \mathrm{NP}$ treatment; respectively. Data are represented as means $\pm \mathrm{SD}$, $n=3 .{ }^{* *} p<0.01$, significantly different from the control group.

As shown in Figure 8a-d, real-time reverse-transcription polymerase chain reaction (qRT-PCR) results revealed that expression levels of $I L-1 \beta, I L-6, I L-8$, and TNF- $\alpha$ were 
significantly increased in a dose-dependent manner in NCI-H292 cells treated with $\mathrm{TiO}_{2} \mathrm{NPs}$ compared with those in the control group.

(a)

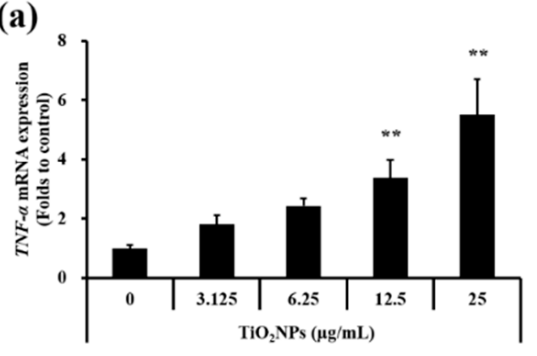

\section{(c)}

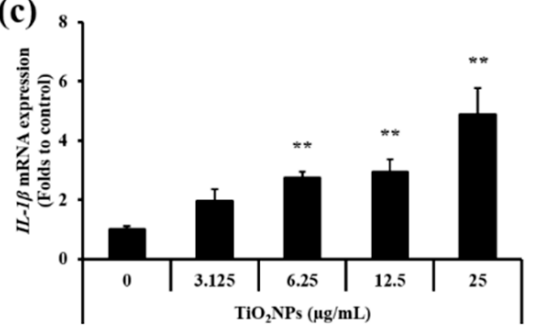

(b)

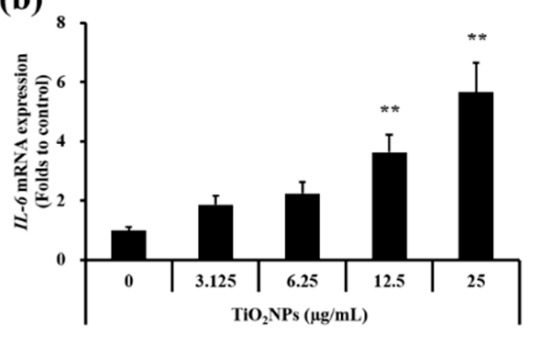

(d)

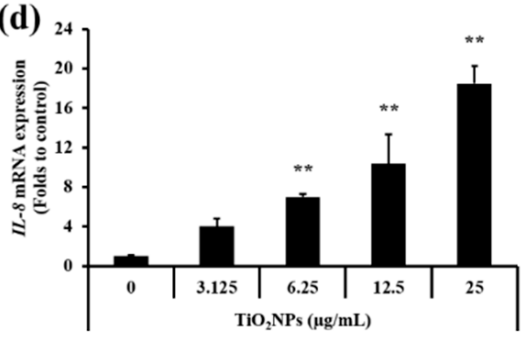

Figure 8. Effects of $\mathrm{TiO}_{2} \mathrm{NP}$ treatment on mRNA expression of inflammatory cytokines measured by qRT-PCR in NCI-H292 cells. (a) TNF- $\alpha$ mRNA expression. (b) IL-6 mRNA expression. (c) IL$1 \beta$ mRNA expression. (d) IL-8 mRNA expression. Control, PBS treatment; 3.125, 6.25, 12.5, and $25 \mu \mathrm{g} / \mathrm{mL}$ of $\mathrm{TiO}_{2} \mathrm{NPs}$ treatment; respectively. Data are represented as means $\pm \mathrm{SD}, n=3$. ${ }^{* *} p<0.01$, significantly different from the control group.

\subsection{Effects of $\mathrm{TiO}_{2} \mathrm{NPS}$ on TXNIP and Apoptosis Protein Expression in NCI-H292 Cells}

Immunoblotting revealed a dose-dependent rise in TXNIP expression and in levels of p-ASK1, Bax, and cleaved-Cas3 in $\mathrm{TiO}_{2} \mathrm{NP}$-treated cells compared to those in untreated cells (Figure $9 \mathrm{a}, \mathrm{b}$ ). To determine the role of TXNIP in mediating effects of $\mathrm{TiO}_{2} \mathrm{NPs}$, we transfected NCI-H292 cells with TXNIP-specific small interfering RNA (siRNA). The control siRNA did not have any effect on the increased expression of p-ASK1, Bax, and cleavedCas3 and $\mathrm{Bc} 22$ expression decreased with $\mathrm{TiO}_{2} \mathrm{NP}$ treatment; however, treatment with TXNIP-specific siRNA diminished the expression of Bax and cleaved-Cas3 and increased the expression of $\mathrm{Bcl} 2$ in $\mathrm{TiO}_{2} \mathrm{NP}$-treated cells, restoring them to levels similar to those in the control group (Figure 10a,b).

(a)

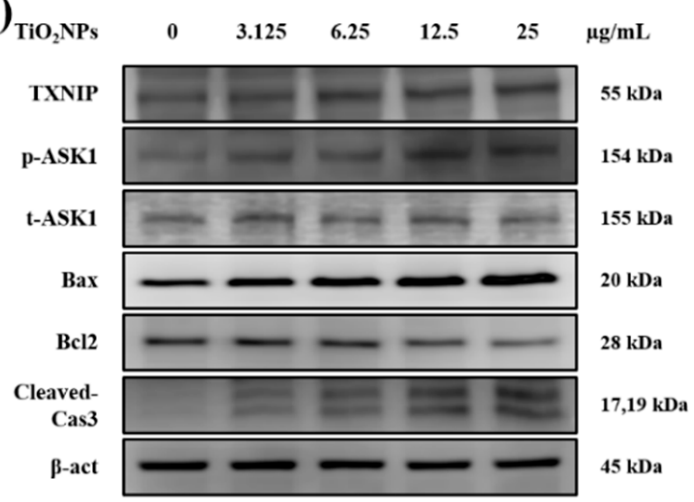

(b)

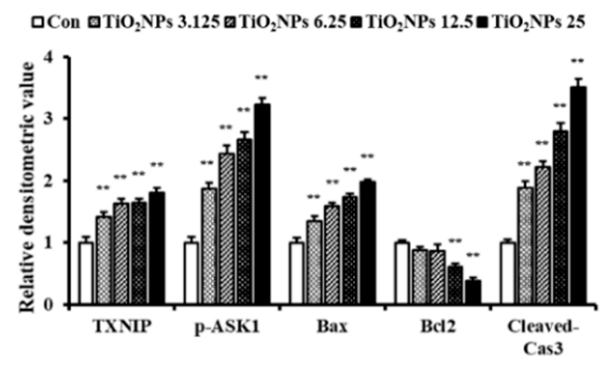

Figure 9. Effects of $\mathrm{TiO}_{2} \mathrm{NP}$ treatment on the expression of TXNIP, p-ASK1, t-ASK1, Bax, Bcl2, and cleaved-Cas3 in NCI-H292 cells. (a) Protein expression is determined using western blotting. (b) Relative densitometric values of protein expression. Control, PBS treatment; $3.125,6.25,12.5$, and $25 \mu \mathrm{g} / \mathrm{mL}$ of $\mathrm{TiO}_{2} \mathrm{NPs}$ treatment; respectively. Data are represented as means $\pm \mathrm{SD}, n=3 .{ }^{* *} p<0.01$, significantly different from the control group. 


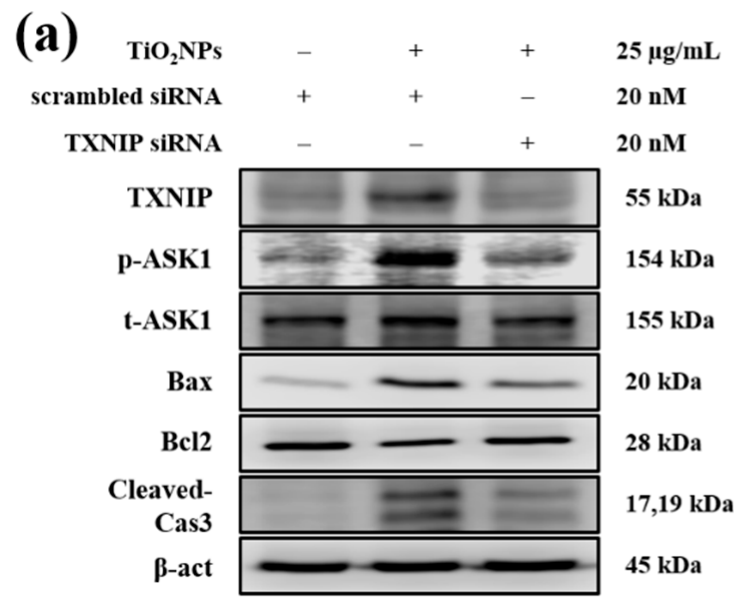

(b)

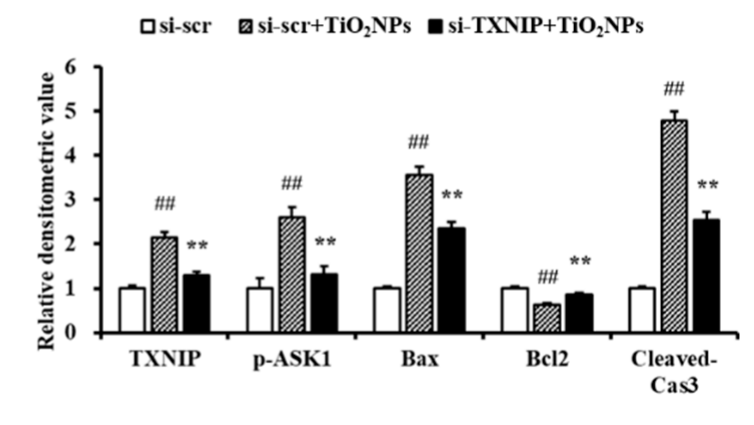

Figure 10. Effects of TXNIP knockdown on $\mathrm{TiO}_{2} \mathrm{NP}$-induced apoptosis in NCI-H292 cells. (a) Proteins expression was determined by western blotting. (b) Relative densitometric values of protein expression. Si-scr, scrambled siRNA $20 \mathrm{nM}$

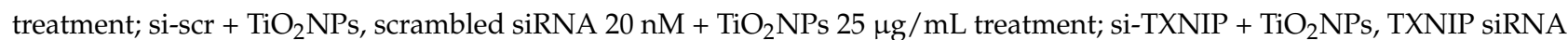
$20 \mathrm{nM}+\mathrm{TiO}_{2} \mathrm{NPs} 25 \mu \mathrm{g} / \mathrm{mL}$ treatment. Data are represented as means $\pm \mathrm{SD}, n=3 .{ }^{\#} p<0.01$, significantly different from the si-scr group; ${ }^{* *} p<0.01$, significantly different from the si-scr $+\mathrm{TiO}_{2} \mathrm{NPs}$ group.

\section{Discussion}

There has been an increase in the number of patients with underlying respiratory diseases, a vulnerable subpopulation who warrant consideration when evaluating the potential respiratory toxicity of various substances [20]. The aim of this study was to examine the effect of $\mathrm{TiO}_{2} \mathrm{NPs}$ on asthma exacerbation and to elucidate its underlying mechanism. We showed that exposure to $\mathrm{TiO}_{2} \mathrm{NPs}$ aggravated asthma, increased TXNIP expression, and activated apoptosis in lungs of OVA-induced mice. Furthermore, $\mathrm{TiO}_{2} \mathrm{NP}$ treatment of NCI-H292 cells led to an upregulation of apoptotic machinery via upregulation in TXNIP.

In this study, exposure to $\mathrm{TiO}_{2} \mathrm{NPs}$ increased the inflammatory response in the respiratory tract and aggravated major asthma symptoms, namely, airway inflammation, airway remodeling, mucus overproduction, and AHR, in mice with OVA-induced asthma. Eosinophilic inflammatory response, which is characteristic of asthma, is known to be induced by IL-4, IL-5, and IL-13 produced by CD4 ${ }^{+} \mathrm{T}$ helper type 2 (Th2) cells [21]. Furthermore, proinflammatory cytokines such as TNF- $\alpha$, IL-6, and IL-1 $\beta$, function as growth factors for B cells and play an important role in the differentiation of $\mathrm{CD} 4^{+} \mathrm{Th} 2$ cells [22]. These cytokines have been reported to increase the secretion of mucus by stimulating goblet cells of bronchi, resulting in AHR [23,24]. Asthmatic mice exposed to $\mathrm{TiO}_{2} \mathrm{NPs}$ exhibited a characteristic increase in cytokines, further heightening the aforementioned major asthma symptoms. Moreover, in this study, IgE level was elevated upon exposure to $\mathrm{TiO}_{2} \mathrm{NPs}$ in asthmatic mice, and such an increase has been reported to be associated with the overproduction of Th2 type cytokines [25]. Overproduction of IgE and Th2 cytokines is observed in asthmatic patients with the eosinophilic asthma phenotype as well as in asthmatic animals $[15,25]$. We observed that cytokine production was significantly increased in NCI-H292 cells treated with $\mathrm{TiO}_{2} \mathrm{NPs}$, which was similar to our in vivo observations. These results were consistent with histological evidence. Exposure to $\mathrm{TiO}_{2} \mathrm{NPs}$ induced inflammatory cell infiltration into lung tissue and mucus production from goblet cells in a dose-dependent manner and aggravated airway inflammatory responses and mucus production in OVA-induced asthmatic animals. Thus, we demonstrated that $\mathrm{TiO}_{2} \mathrm{NPs}$ caused respiratory toxicity and exacerbated asthma, which is consistent with the findings of previous reports $[1,6,26]$.

TXNIP can directly bind to thioredoxin (TRX) and inhibit its function, leading to the activation of an apoptotic signaling pathway. Under normal conditions, TRX inhibits the activation of ASK1 via formation of a complex. However, activated TXNIP induces the 
dissociation of this TRX-ASK1 complex, resulting in the activation of ASK1 and, consequently, apoptosis $[27,28]$. The association between nanoparticles and TXNIP has been reported in several studies $[15,16]$. For example, exposure to silica dioxide nanoparticles has been shown to worsen asthma and increase pulmonary toxicity via upregulation of TXNIP. In this study, exposure to $\mathrm{TiO}_{2} \mathrm{NPs}$ increased TXNIP expression and activated TXNIP downstream signaling in lungs of normal and asthmatic mice. Furthermore, we found that the $\mathrm{TiO}_{2} \mathrm{NP}$-activated apoptosis was suppressed by downregulation of the TXNIP gene in human airway epithelial cells. In contrast, upregulation of TXNIP promotes apoptosis by increasing the $\mathrm{Bax} / \mathrm{Bcl} 2$ ratio and cleaved-caspase 3 expression [19]. Overall, exposure of $\mathrm{TiO}_{2} \mathrm{NPs}$ to mice increased the expression of TXNIP in lungs, demonstrating that TXNIP might be involved in the molecular pathogenesis of asthma. This suggests that TXNIP may be responsible for the aggravating effect of $\mathrm{TiO}_{2} \mathrm{NP}$-induced apoptosis in asthmatic lungs.

In conclusion, exposure to $\mathrm{TiO}_{2} \mathrm{NPs}$ revealed a marked increase in AHR, inflammatory cytokines and responses, and mucus overproduction, which are typical characteristics of asthma, and these characteristic were correlated with those in the apoptotic signaling pathway (Figure 11). Moreover, we elucidated the aggravating effect of $\mathrm{TiO}_{2} \mathrm{NP}$ inhalation in respiratory tracts with asthma, along with the molecular pathogenesis through the regulation of TXNIP. Thus, our present study provides useful information on new target signaling not yet observed in $\mathrm{TiO}_{2} \mathrm{NP}$-induced asthmatic lung tissues.

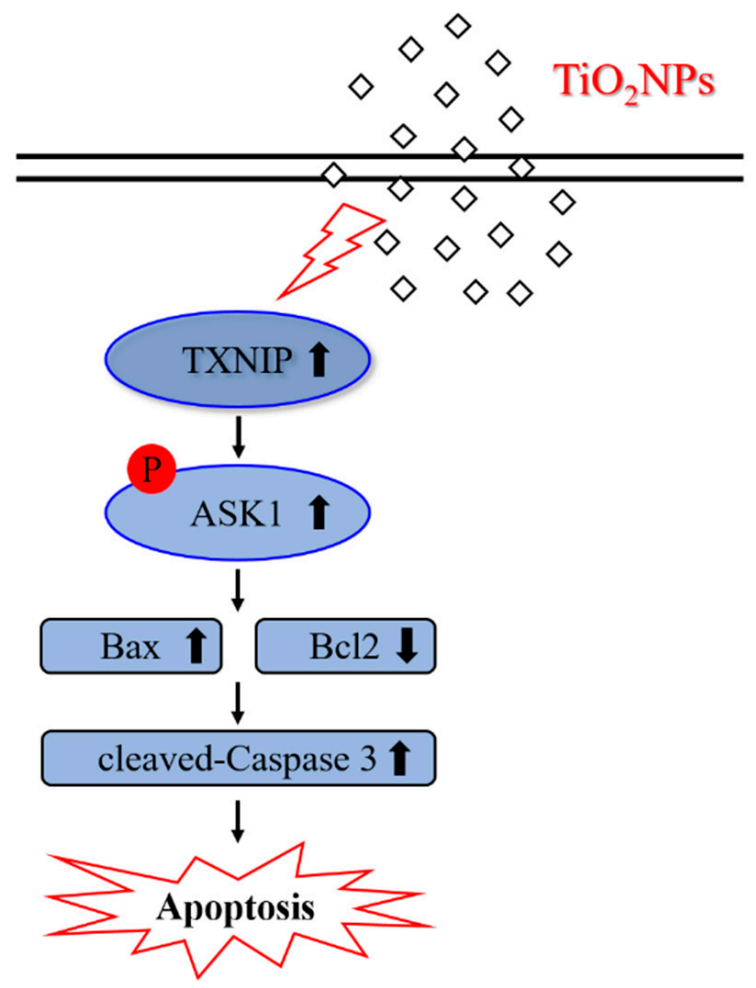

Figure 11. Proposed signaling pathway for $\mathrm{TiO}_{2} \mathrm{NP}$-induced apoptosis in the lung of asthmatic mice. TXNIP levels are increased by exposure to $\mathrm{TiO}_{2} \mathrm{NP}$ phosphorylates ASK1, thereby increasing apoptosis. TXNIP plays a key mediator role in the exacerbation of asthma by $\mathrm{TiO}_{2} \mathrm{NPs}$.

\section{Materials and Methods}

\subsection{Characterization of $\mathrm{TiO}_{2} \mathrm{NPS}_{\mathrm{S}}$}

$\mathrm{TiO}_{2} \mathrm{NPs}$ were purchased from Sigma-Aldrich (particle size $<25 \mathrm{~nm}, 637254$, St. Louis, $\mathrm{MO}$, USA). We quantified the morphology and size of $\mathrm{TiO}_{2} \mathrm{NPs}$ using transmission electron microscopy (JEM-1210, JEOL, Tokyo, Japan) and scanning electron microscopy (Zeiss EVOMA10; Carl Zeiss Meditec AG, Jena, Germany) at accelerating voltages of $200 \mathrm{kV}$ and $15 \mathrm{kV}$, respectively. The specific surface area of $\mathrm{TiO}_{2} \mathrm{NPs}$ was measured by nitrogen absorption 
methods based on the multipoint BET method (ASAP2020; Micromeritics, Norcross, GA, USA). The hydrodynamic size and zeta potential of $\mathrm{TiO}_{2} \mathrm{NPs}$ were determined by ELS-8000 (Otsuka Electronic, Tokyo, Japan). The purity of $\mathrm{TiO}_{2} \mathrm{NPs}$ used in the experiment was determined by energy-dispersive X-ray spectroscopy (Rayny EDX-700, Shimadzu, Kyoto, Japan). The endotoxin levels in thee $\mathrm{TiO}_{2} \mathrm{NP}$ suspension were determined using a Pierce LAL Chromogenic Endotoxin Quantitation Kit (Thermo Fisher Scientific, Waltham, MA, USA). After completion of treatment procedures, lung tissue was harvested, weighed, and digested overnight with concentrated nitric acid, and the resultant samples were analyzed for elemental $\mathrm{TiO}_{2} \mathrm{NPs}$ using ICP-MS (Perkin Elmer, Waltham, MA, USA).

\subsection{Experimental Procedure for Allergic Asthma Induction}

Specific pathogen-free female BALB/c mice (six weeks old) were purchased from Samtako Co. (Osan, Korea) quarantined and acclimatized for seven days. Animals were confined at $22 \pm 2{ }^{\circ} \mathrm{C}$ in a room with a relative humidity of $50 \pm 5 \%$, artificial lighting from 08:00-20:00, and 13-18 air changes per hour. Animals were provided ad libitum access to a standard laboratory diet (Samtako Co., Osan, Korea) and water. All experimental procedures were carried out in accordance with the National Institute Health Guidelines for the Care and Use of Laboratory Animals. The Institutional Animal Care and Use Committee of Chonnam National University approved experimental protocols involving animals (CNU IACUC-YB-2020-19).

To investigate pulmonary toxicity of $\mathrm{TiO}_{2} \mathrm{NPs}, 24$ healthy female mice were randomly assigned to four experimental groups ( $n=6$ per group); $\mathrm{VC}$ group and three $\mathrm{TiO}_{2} \mathrm{NPs}_{\text {s-treated }}$ $\left(5,10\right.$, and $20 \mathrm{mg} / \mathrm{kg}$, respectively) groups. On days 1,3 , and 5, animals of the $\mathrm{TiO}_{2} \mathrm{NP}$ treated groups $\left(5,10\right.$, and $20 \mathrm{mg} / \mathrm{kg}$ doses in $50 \mu \mathrm{L}$ of PBS, respectively) received $\mathrm{TiO}_{2} \mathrm{NPs}$ via intranasal instillation under light anesthesia using Zoletil $50^{\circledR}$ (Virbac Laboratories, Carros, France). The VC group received $50 \mu \mathrm{L}$ of PBS via intranasal instillation. $\mathrm{TiO}_{2} \mathrm{NPs}$ were prepared in PBS and sonicated in an ultrasonicator (VCX-130, Sonics and Materials, Newtown, CT, USA) for $3 \mathrm{~min}(130 \mathrm{~W}, 20 \mathrm{kHz}$, pulse 59/1) before intranasal instillation.

To investigate the effect of $\mathrm{TiO}_{2} \mathrm{NPs}$ on the development of asthma, 30 animals were randomly assigned to five experimental groups (each group, $n=6$ ); VC group, OVA group, and three OVA+ $\mathrm{TiO}_{2} \mathrm{NPs}(5,10$, and $20 \mathrm{mg} / \mathrm{kg}$ ) groups. On days 1 and 15, mice were sensitized with an intraperitoneal injection of $20 \mu \mathrm{g}$ of OVA (Sigma-Aldrich, St. Louis, MO, USA) emulsified with $2 \mathrm{mg}$ of aluminum hydroxide (Thermo Scientific, Waltham, MA, USA) in $200 \mu \mathrm{L}$ of PBS (pH 7.4). On days 22,24 , and 26 , mice received a $1 \mathrm{~h}$ airway challenge with $1 \%(w / v)$ OVA solution aerosolized using an ultrasonic nebulizer (NE-U12; Omron Corp., Tokyo, Japan). On days 21, 23, and 25, mice of the $\mathrm{TiO}_{2} \mathrm{NP}$ treatment groups $\left(5,10\right.$, and $20 \mathrm{mg} / \mathrm{kg}$ doses in $50 \mu \mathrm{L}$ of PBS, respectively) received $\mathrm{TiO}_{2} \mathrm{NPs}_{\text {via intranasal }}$ instillation under light anesthesia using Zoletil $50^{\circledR}$ (Virbac Laboratories). The VC and OVA

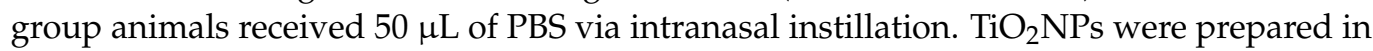
PBS and sonicated in an ultrasonicator for $3 \mathrm{~min}$ before intranasal instillation.

\subsection{Measurement of Airway AHR}

Penh values were indirectly assessed $24 \mathrm{~h}$ after the final intranasal instillation via single-chamber whole body plethysmography (Allmedicus, Seoul, Korea). Mice were anesthetized for a brief period with an intraperitoneal injection of a mixture of Zoletil and Xylazine $(40 \mathrm{mg} / \mathrm{kg}$ and $10 \mathrm{mg} / \mathrm{kg}$, respectively), subsequently placed in a chamber, and nebulized with aerosolized PBS or methacholine in increasing concentrations $(10,20$, and $40 \mathrm{mg} / \mathrm{mL})$.

\subsection{Collection of Bronchoalveolar Lavage Fluid (BALF) and Cell Counting}

Mice were sacrificed at $24 \mathrm{~h}$ after measurement of AHR via an intraperitoneal injection of Zoletil $50^{\circledR}$ (Virbac Laboratories), and a tracheostomy was performed. To obtain BALF, ice-cold PBS $(0.7 \mathrm{~mL})$ was infused into their lungs twice and subsequently withdrawn each time using a tracheal cannula (a total volume of $1.4 \mathrm{~mL}$ ). BALF samples were centrifuged, 
and its supernatant was collected for biochemical analysis. Collected cells were resuspended in ice-cold PBS $(0.5 \mathrm{~mL})$, and $200 \mu \mathrm{L}$ of the resuspended solution was centrifuged $\left(200 \times g, 4{ }^{\circ} \mathrm{C}, 10 \mathrm{~min}\right)$ onto slides using a cytospin (Hanil Science Industrial Co., Ltd., Seoul, Korea). Slides were dried, and the cells were fixed and stained. Differential cell counts were performed using the Diff-Quik ${ }^{\circledR}$ staining reagent (Sysmex Corporation, Kobe, Japan) according to the manufacturer's instructions.

\subsection{Cytokines Assay}

Levels of several cytokines in BALF, namely TNF- $\alpha$, IL-6, IL-1 $\beta$, IL-5, and IL-13, were measured using commercial enzyme-linked immunosorbent assay (ELISA) kits (BD Biosciences, San Jose, CA, USA) according to the manufacturer's protocol. The serum level of OVA-specific IgE was measured using an ELISA kit (BioLegend, San Diego, CA, USA). Absorbance was measured at $450 \mathrm{~nm}$ using an ELISA reader (Bio-Rad Laboratories, Hercules, CA, USA).

\subsection{Histopathology and IHC}

After BALF samples were collected, the lung tissue was fixed with $4 \%(v / v)$ paraformaldehyde for $48 \mathrm{~h}$. Tissues were paraffin-embedded, sectioned at a thickness of $4 \mu \mathrm{m}$ and stained using hematoxylin and eosin (Sigma-Aldrich, St. Louis, MO, USA) or periodic acid-Schiff solution (IMEB Inc., San Marcos, CA, USA) to evaluate airway inflammation and mucus production, respectively. Furthermore, sectioned tissues were processed for IHC, as previously described [29]. The primary antibodies used for the detection of protein expression were anti-TXNIP (NBP1-54578; 1:200 dilution; Novus Biologicals, Littleton, CO, USA) and anti-cleaved-Cas3 (\#9661; 1:200 dilution; Cell signaling, Danvers, MA, USA). Each slide was examined manually by investigators blind to the treatment groups using a light microscope (Leica, Wetzlar, Germany) with $10 \times$ and $20 \times$ objective lenses and a $100 \times$ oil immersion lens. Ten randomly selected nonoverlapping areas per slide were captured with a digital camera (IMTcamCCD5; IMT Inc., Daejeon, Korea), and quantitative analyses of airway inflammation, mucus production, and protein expression were performed using an image analyzer (IMT i-Solution software, Vancouver, BC, Canada).

\subsection{Western Blot Analysis}

To quantify protein expression, we performed immunoblotting as previously described [30]. Primary antibodies used are as follows: anti-TXNIP (NBP1-54578; Novus Biologicals), anti-p-ASK1 (SAB4504337; Sigma-Aldrich, St. Louis, MO, USA), anti-totalASK1 (t-ASK1, ab45178; Abcam, Cambridge, UK), anti-Bcl2 (\#2876; Cell Signaling, Danvers, MA, USA), anti-Bax (\#2772; Cell Signaling), anti-cleaved-Cas3 (\#9661; Cell Signaling), and anti- $\beta$-actin ( $\beta$-act, $\# 4967$; Cell Signaling). Densitometric analysis of expression was performed using Chemi-Doc (Bio-Rad Laboratories).

\subsection{Cell Culture}

The human airway epithelial cell line NCI-H292 was obtained from the American Type Culture Collection (Manassas, VA, USA). Cells were grown in RPMI 1640 medium (WELGENE, Gyeongsan, Korea) with 10\% fetal bovine serum, streptomycin $(100 \mu \mathrm{g} / \mathrm{mL}$ ), and penicillin $(100 \mathrm{U} / \mathrm{mL})$ and incubated in a humidified chamber maintained at $37{ }^{\circ} \mathrm{C}$ with $5 \% \mathrm{CO}_{2}$. Cells were serum-starved for $1 \mathrm{~h}$ before use.

\subsection{Cell Viability Assay}

Cell viability was performed using the EZ-Cytox cell viability assay kit (DAELIL lab, Seoul, Korea), and concentration of $\mathrm{TiO}_{2} \mathrm{NPs}$ was chosen with reference to a previous study [31]. NCI-H292 cells were seeded in 96 well-plates $\left(4 \times 10^{4}\right.$ cells/well). After $24 \mathrm{~h}$, fresh medium and various concentrations of $\mathrm{TiO}_{2} \mathrm{NPs}(1.56,3.13,6.25,12.5,25 \mu \mathrm{g} / \mathrm{mL})$ were added. The culture plate was incubated for another $24 \mathrm{~h}$. Eventually, viable cells were determined by adding $10 \mu \mathrm{L}$ of the kit solution to each well before incubating for 
$4 \mathrm{~h}$. Absorbance was measured at $450 \mathrm{~nm}$ using an ELISA reader (Bio-Rad Laboratories, Hercules, CA, USA).

\subsection{Measurement of mRNA Expression of Proinflammatory Cytokines in NCI-H292 Cells}

RNA was isolated using the HiGene Total RNA Prep Kit (Biofact, Daejeon, Korea) according to the manufacturer's protocol. RNA concentration (A260) and purity (A260/A280 ratio) was measured by spectrophotometry (NanoDrop One Microvolume UV-Vis Spectrophotometer, Thermo Fisher Scientific, Dreieich, Germany), and the ratio for pure RNA A260/280 was higher than 2.0. The total RNA was reverse transcribed into cDNA using a cDNA kit (Qiagen, Hilden, Germany). CFX Connect Real-Time PCR Detection System (1855201, Bio-Rad Laboratories, Hercules, CA, USA) and CFX manager software (1845000 version 3.1, Bio-Rad Laboratories, Hercules, CA, USA) were used to quantify proinflammatory cytokine mRNA expression for RT-qPCR. qRT-PCR experiments were performed using specific forward and reverse primers (Table S1) and the conditions were as follows: 15 min at $95^{\circ} \mathrm{C}, 20 \mathrm{~s}$ at $95^{\circ} \mathrm{C} / 40 \mathrm{~s}$ at $55^{\circ} \mathrm{C}$ for 40 cycles, and $10 \mathrm{~s}$ at $95^{\circ} \mathrm{C} / 5 \mathrm{~s}$ at $65{ }^{\circ} \mathrm{C} / 60 \mathrm{~s}$ at $95{ }^{\circ} \mathrm{C}$ for the melting curve. The qRT-PCR reaction system was $20 \mu \mathrm{L}$ : SYBR Premix (Biofact)I, $10 \mu \mathrm{L}$; PCR Forward Primer $(10 \mu \mathrm{M}), 1 \mu \mathrm{L}$; PCR Reverse Primer $(10 \mu \mathrm{M}), 1 \mu \mathrm{L}$; cDNA template, $2 \mu \mathrm{L}$; and distilled water, $6 \mu \mathrm{L}$. The mRNA expressions of IL-6, IL-1 $\beta$, and TNF- $\alpha$ were calculated by the $2^{-\Delta \Delta C T}$ method with the internal reference as GAPDH.

\subsection{Small Interfering RNA Transfection of NCI-H292 Cells}

TXNIP-specific siRNA (4392420) and scrambled siRNA (4390843) were purchased from Ambion (Waltham, MA, USA). Each siRNA ( $20 \mathrm{nM})$ was transfected into NCI-H292 cells using LipofectamineTM RNAiMAX reagent (Invitrogen, Waltham, MA, USA) following the forward transfection method, as prescribed by the manufacturer. After suppression of endogenous TXNIP expression, cells were treated with $25 \mu \mathrm{g} / \mathrm{mL} \mathrm{TiO}{ }_{2} \mathrm{NPs}_{\text {or }}$ PBS and harvested after $6 \mathrm{~h}$. To investigate the protein expression involved in TXNIP-apoptosis signaling, western blot was performed as above-mentioned.

\subsection{Statistical Analysis}

Data were expressed as means \pm standard deviation (SD). Statistical significance was determined using analysis of variance followed by Dunnett's test for multiple comparisons. $p$ values less than 0.05 were considered statistically significant.

Supplementary Materials: The following are available online at https://www.mdpi.com/article/10.3 390/ijms22189924/s1.

Author Contributions: Conceptualization, J.-W.K. and J.-C.K.; Methodology, J.-O.L., C.M., J.-D.H. and I.-S.S.; Formal analysis, J.-O.L., S.-J.L., W.-I.K. and S.-W.P.; Investigation, J.-O.L. and C.M.; Resources, J.-W.K., J.-D.H. and I.-S.S.; Data curation, J.-W.K. and J.-C.K.; Writing-original draft preparation, J.-O.L.; Writing-review and editing, J.-W.K. and J.-C.K.; Supervision, J.-C.K.; Project administration, J.-O.L. and S.-J.L. All authors have read and agreed to the published version of the manuscript.

Funding: This work was supported by the National Research Foundation of Korea (NRF) grant funded by the Korea Government (MSIT) (NRF-2020R1A2C210259611). This work was also supported by the National Research Foundation of Korea (NRF) grant funded by the Korean Government (MSIT) (NRF-2020R1A4A1019395).

Institutional Review Board Statement: All experimental procedures were carried out in accordance with the National Institute Health Guidelines for the Care and Use of Laboratory Animals. The Institutional Animal Care and Use Committee of Chonnam National University approved experimental protocols involving animals (CNU IACUC-YB-2020-19).

Informed Consent Statement: Not applicable.

Data Availability Statement: Not applicable.

Conflicts of Interest: The authors declare no conflict of interest. 


\section{References}

1. Jonasson, S.; Gustafsson, A.; Koch, B.; Bucht, A. Inhalation exposure of nano-scaled titanium dioxide (TiO2) particles alters the inflammatory responses in asthmatic mice. Inhal. Toxicol. 2013, 25, 179-191. [CrossRef]

2. Da Silva, A.L.; Cruz, F.F.; Rocco, P.R.M.; Morales, M.M. New perspectives in nanotherapeutics for chronic respiratory diseases. Biophys. Rev. 2017, 9, 793-803. [CrossRef]

3. Ihrie, M.D.; Bonner, J.C. The toxicology of engineered nanomaterials in asthma. Curr. Environ. Health Rep. 2018, 5, 100-109. [CrossRef]

4. Dasari, K.B.; Cho, H.; Jaćimović, R.; Sun, G.M.; Yim, Y.H. Chemical composition of asian dust in daejeon, korea, during the spring season. ACS Earth Space Chem. 2020, 4, 1227-1236. [CrossRef]

5. Ambalavanan, N.; Stanishevsky, A.; Bulger, A.; Halloran, B.; Steele, C.; Vohra, Y.; Matalon, S. Titanium oxide nanoparticle instillation induces inflammation and inhibits lung development in mice. Am. J. Physiol. Lung Cell. Mol. Physiol. 2013, 304, L152-L161. [CrossRef]

6. Kim, B.G.; Lee, P.H.; Lee, S.H.; Park, M.K.; Jang, A.S. Effect of $\mathrm{TiO}_{2}$ nanoparticles on inflammasome-mediated airway inflammation and responsiveness. Allergy Asthma Immunol. Res. 2017, 9, 257-264. [CrossRef]

7. Frey, S.M.; Jones, M.R.; Goldstein, N.; Riekert, K.; Fagnano, M.; Halterman, J.S. Knowledge of inhaled therapy and responsibility for asthma management among young teens with uncontrolled persistent asthma. Acad. Pediatr. 2018, 18, 317-323. [CrossRef] [PubMed]

8. Alharris, E.; Alghetaa, H.; Seth, R.; Chatterjee, S.; Singh, N.P.; Nagarkatti, M.; Nagarkatti, P. Resveratrol attenuates allergic asthma and associated inflammation in the lungs through regulation of miRNA-34a that targets FoxP3 in mice. Front. Immunol. 2018, 9, 2992. [CrossRef] [PubMed]

9. Menzel, M.; Ramu, S.; Calvén, J.; Olejnicka, B.; Sverrild, A.; Porsbjerg, C.; Tufvesson, E.; Bjermer, L.; Akbarshahi, H.; Uller, L. Oxidative stress attenuates TLR3 responsiveness and impairs anti-viral mechanisms in bronchial epithelial cells from COPD and asthma patients. Front. Immunol. 2019, 10, 2765. [CrossRef] [PubMed]

10. Choi, Y.; Sim, S.; Park, H.S. Distinct functions of eosinophils in severe asthma with type 2 phenotype: Clinical implications. Korean J. Intern. Med. 2020, 35, 823-833. [CrossRef] [PubMed]

11. Kim, H.Y.; DeKruyff, R.H.; Umetsu, D.T. The many paths to asthma: Phenotype shaped by innate and adaptive immunity. Nat. Immunol. 2010, 11, 577-584. [CrossRef] [PubMed]

12. Lerner, A.G.; Upton, J.P.; Praveen, P.V.; Ghosh, R.; Nakagawa, Y.; Igbaria, A.; Shen, S.; Nguyen, V.; Backes, B.J.; Heiman, M.; et al. IRE1alpha induces thioredoxin-interacting protein to activate the NLRP3 inflammasome and promote programmed cell death under irremediable ER stress. Cell Metab. 2012, 16, 250-264. [CrossRef] [PubMed]

13. Abdelsaid, M.A.; Matragoon, S.; Ergul, A.; El-Remessy, A.B. Deletion of thioredoxin interacting protein (TXNIP) augments hyperoxia-induced vaso-obliteration in a mouse model of oxygen induced-retinopathy. PLoS ONE 2014, 9, e110388. [CrossRef]

14. Mohamed, I.N.; Sarhan, N.R.; Eladl, M.A.; El-Remessy, A.B.; El-Sherbiny, M. Deletion of thioredoxin-interacting protein ameliorates high fat diet-induced non-alcoholic steatohepatitis through modulation of toll-like receptor 2-NLRP3-inflammasome axis: Histological and immunohistochemical study. Acta. Histochem. 2018, 120, 242-254. [CrossRef] [PubMed]

15. Ko, J.W.; Shin, N.R.; Lim, J.O.; Jung, T.Y.; Moon, C.; Kim, T.W.; Choi, J.; Shin, I.S.; Heo, J.D.; Kim, J.C. Silica dioxide nanoparticles aggravate airway inflammation in an asthmatic mouse model via NLRP3 inflammasome activation. Regul. Toxicol. Pharmacol. 2020, 112, 104618. [CrossRef] [PubMed]

16. Lim, J.O.; Ko, J.W.; Jung, T.Y.; Kim, W.I.; Pak, S.W.; Shin, I.S.; Yun, W.K.; Kim, H.C.; Heo, J.D.; Kim, J.C. Pulmonary inflammation caused by silica dioxide nanoparticles in mice via TXNIP/NLRP3 signaling pathway. Mol. Cell. Toxicol. 2020, 16, $245-252$. [CrossRef]

17. Zhou, W.; Shao, W.; Zhang, Y.; Liu, D.; Liu, M.; Jin, T. Glucagon-like peptide-1 receptor mediates the beneficial effect of liraglutide in an acute lung injury mouse model involving the thioredoxin-interacting protein. Am. J. Physiol. Endocrinol. Metab. 2020, 319, E568-E578. [CrossRef] [PubMed]

18. Chihara, Y.; Iizumi, Y.; Horinaka, M.; Watanabe, M.; Goi, W.; Morita, M.; Nishimoto, E.; Sowa, Y.; Yamada, T.; Takayama, K.; et al. Histone deacetylase inhibitor OBP-801 and amrubicin synergistically inhibit the growth of squamous cell lung carcinoma by inducing mitochondrial ASK1-dependent apoptosis. Int. J. Oncol. 2020, 56, 848-856. [CrossRef]

19. Deng, W.; Li, Y.; Jia, Y.; Tang, L.; He, Q.; Liu, D. Over-expression of thioredoxin-interacting protein promotes apoptosis of MIN6 cells via activating p38MAPK pathway. Xi Bao Yu Fen Zi Mian Yi Xue Za Zhi 2017, 33, 1323-1327.

20. Izquierdo, J.L.; Almonacid, C.; González, Y.; Del Rio-Bermudez, C.; Ancochea, J.; Cárdenas, R.; Lumbreras, S.; Soriano, J.B. The impact of COVID-19 on patients with asthma. Eur. Respir. J. 2021, 57, 2003142. [CrossRef]

21. Abdulnasser Harfoush, S.; Hannig, M.; Le, D.D.; Heck, S.; Leitner, M.; Omlor, A.J.; Tavernaro, I.; Kraegeloh, A.; Kautenburger, R.; Kickelbick, G.; et al. High-dose intranasal application of titanium dioxide nanoparticles induces the systemic uptakes and allergic airway inflammation in asthmatic mice. Respir. Res. 2020, 21, 168. [CrossRef] [PubMed]

22. Ma, J.; Chan, C.C.; Huang, W.C.; Kuo, M.L. Berberine inhibits pro-inflammatory cytokine-induced IL-6 and CCL11 production via modulation of STAT6 pathway in human bronchial epithelial cells. Int. J. Med. Sci. 2020, 17, 1464-1473. [CrossRef] [PubMed]

23. Shi, H.; Magaye, R.; Castranova, V.; Zhao, J. Titanium dioxide nanoparticles: A review of current toxicological data. Part. Fibre Toxicol. 2013, 10, 15. [CrossRef] 
24. Tanabe, T.; Rubin, B.K. Airway goblet cells secrete pro-inflammatory cytokines, chemokines, and growth factors. Chest 2016, 149, 714-720. [CrossRef]

25. Manise, M.; Holtappels, G.; Van Crombruggen, K.; Schleich, F.; Bachert, C.; Louis, R. Sputum IgE and cytokines in asthma: Relationship with sputum cellular profile. PLoS ONE 2013, 8, e58388. [CrossRef]

26. Mishra, V.; Baranwal, V.; Mishra, R.K.; Sharma, S.; Paul, B.; Pandey, A.C. Titanium dioxide nanoparticles augment allergic airway inflammation and Socs3 expression via NF-kappaB pathway in murine model of asthma. Biomaterials 2016, 92, 90-102. [CrossRef]

27. Hsieh, C.C.; Papaconstantinou, J. Thioredoxin-ASK1 complex levels regulate ROS-mediated p38 MAPK pathway activity in livers of aged and long-lived Snell dwarf mice. FASEB J. 2006, 20, 259-268. [CrossRef]

28. Malone, C.F.; Emerson, C.; Ingraham, R.; Barbosa, W.; Guerra, S.; Yoon, H.; Liu, L.L.; Michor, F.; Haigis, M.; Macleod, K.F.; et al mTOR and HDAC inhibitors converge on the TXNIP/thioredoxin pathway to cause catastrophic oxidative stress and regression of RAS-driven tumors. Cancer Discov. 2017, 7, 1450-1463. [CrossRef]

29. Lim, J.O.; Shin, N.R.; Seo, Y.S.; Nam, H.H.; Ko, J.W.; Jung, T.Y.; Lee, S.J.; Kim, H.J.; Cho, Y.K.; Kim, J.C.; et al. Silibinin attenuates silica dioxide nanoparticles-induced inflammation by suppressing TXNIP/MAPKs/AP-1 signaling. Cells 2020, 9, 678. [CrossRef]

30. Shin, I.S.; Shin, N.R.; Park, J.W.; Jeon, C.M.; Hong, J.M.; Kwon, O.K.; Kim, J.S.; Lee, I.C.; Kim, J.C.; Oh, S.R.; et al. Melatonin attenuates neutrophil inflammation and mucus secretion in cigarette smoke-induced chronic obstructive pulmonary diseases via the suppression of Erk-Sp1 signaling. J. Pineal Res. 2015, 58, 50-60. [CrossRef]

31. Okuda-Shimazaki, J.; Takaku, S.; Kanehira, K.; Sonezaki, S.; Taniguchi, A. Effects of titanium dioxide nanoparticle aggregate size on gene expression. Int. J. Mol. Sci. 2010, 11, 2383-2392. [CrossRef] [PubMed] 